\title{
THE ABILITY OF BIOGAS AS SUSTAINABLE ENERGY TO MEET RURAL LIVELIHOODS
}

\author{
Amany A. Metwally *
}

\section{ABSTRACT}

The increase in the environmental pollution and economic growth, energy usage requirement cause increase in world clean energy demand. Biomethanization is one of the promised technologies to produce clean and renewable energy source compared to fossil energy resources. This research was done in two trials, the first trial focused on comparing the potential and actual values for heat and electric energy from different biomass hence, select the best for the equal energy required for different livelihoods in rural applications. The second trial, the preferable feedstocks synthesis $(25 \%$ cattle dung $+75 \%$ poultry droppings) from the first trial was select to apply in the second fermentation, which done in home scale digester (68l) under three different agitations at under mesophilic temperature $38^{\circ} \mathrm{C}$.

The results showed that using a combination of feedstocks (co-digestion) led to improving the biogas yield by $67.68 \%-7.10 \%$ because of the increase in organic content and optimizing the conditions for anaerobic digestion. Also, the percentage for every row feedstock in the combination has an equally significant aspect. The calorific efficiency was average $54-78 \%$ and correspondingly, the electricity produced efficiency ranged between 52.43 $68.09 \%$. Hence, the combinations of feedstocks can be selected to be enough to purposes of heat and electricity applications.

In the home scale digester, the regression equation for methane yield to retention time under two-time agitation per day was $y=0.347 x+0.5016 x^{2}$ $0.0162 x^{3}$. In additional it was found that the biogas production was 3993.87 $\mathrm{l}$ month from $25 \mathrm{~kg}$ only of animal wastes, this covered 4 days of cooking or gas lamp demands or 12 days of a refrigerator. Hence, decrease the using of conventional sources and improve the healthy living in rural communities.

\section{INTRODUCTION}

$\mathrm{B}$ iomass transformation by the biological method has a number of advantages such as less energy input demands and the ability to transfer most of the organic substances into biogas, in the home, which lead to reducing energy poverty and economic development.

\footnotetext{
* Lecturer of Agric. Eng., Fac. of Agric., Zagazig Univ. Egypt.
} 
The anaerobic digestion process can reduce operational costs by a large margin compared with high-energy consumptive aerobic processes. Cu et al., (2012) suggest the biogas technology as a method for solving environmental problems, contributing to energy production and resolving economic and social issues. Undoubtedly, the existence of a massive amount of animals' wastes in rural villages causes several environmental problems like polluted air, water and soil. On most farms the cows, poultry and rabbits are the animals whose produce the highest quantities of wastes. Ordinarily, these wastes applied as compost or direct organic fertilizers, which has a low energy processing for material utilization hence, it was beneficial to utilize it's in energy required in order to improve the scientific evidence for waste utilization rather than its pollution. Elfeki and Tkadlec., (2015) reported that animals' amount in the agricultural sector in Egypt is around 18.7 million which produce 14.7 million tons of waste per year.

Miah et al., (2016) suggested that biogas production can be a possible treatment for waste materials; the poultry waste is eligible for anaerobic digestion when mixed with a qualitative percentage of cow dung to take out a bench-mark quantity of potential biogas production with the low-cost process. The specific biogas production obtained related to volatile solids feed were $0.469,0.419 \mathrm{l} / \mathrm{g}$ from (75\% poultry litter with $25 \%$ cow dung $\mathrm{w} / \mathrm{w})$ and (50\% poultry litter with $50 \%$ cow dung w/w), respectively. Also, the methane percentage in the biogas generated varied from 70 to $72.6 \%$.

Hassan (2003) informed that the calorific value of biogas ranges between 17 and $25 \mathrm{MJ} . \mathrm{m}^{-3}$ (natural gas $38 \mathrm{MJ} . \mathrm{m}^{-3}$ ) depending on the amount of methane in biogas. Methane is considered as a valuable fuel. The gas is non-toxic, colorless, odorless, and is lighter than air. Increasing $\mathrm{CO}_{2} \%$ in the biogas leads to the lower calorific value of the produced biogas.

Triolo et al., (2011) noticed that poultry waste content a degradable organic compared to other agricultural waste products, however, the high concentration of solids content (TS \%), which can be more than $20 \%$ make the substrate more difficult in digest, therefore, it is proposed to dilute poultry waste or mixing it with organic wastes in order to make suitable conditions for anaerobic digesters. This is consistent with Wang et al., (2013) who reported the benefits of mixing poultry waste with other 
organic wastes on one installation process as improving the production of biogas, increased the loading of readily biodegradable organics, support balance in $\mathrm{C} / \mathrm{N}$ ratio and nutrients, decrease the toxic components thus produce better quality gas.

As described by Machunga-Disu and Machunga-Disu, (2012) biogas as renewable fuel can be used for various energy services such as heating and combined heat and power plant. Biogas can be burned in boilers with high efficiency $(79 \%)$ to produce hot water and steam also used for electricity generation where two type common engines use for this propose internal combustion engine and gas turbine engine. However, using a combined heat and power (CHP) plant is an excellent way to extract the maximum benefit from biogas for use the waste heat that results from generating electricity. Waste heat recovery can increase the energy efficiency of the system by 40 to $55 \%$ to reach $85 \%$, this heat can be used to heat the digester and/or provide hot water.

Indeed, the analysis of biomass composition can be used for sustainable waste management in many applications of renewable fuels based on bio and agro-waste. Weiland et al., (2009) and Deublein and Steinhauser (2008) confirmed on the relation between the potential methane production to biomass content of lipid, carbohydrate and protein from animals wastes as a volatile solid percentage. As mentioned by Alfa et al., (2014) the generation of biogas from cow dung was faster compared to poultry droppings, this related to the rapid decomposition for animal intestinal wastes from cow and poultry, respectively. In addition, the methane percentage was estimated to be $65.59 \%$ and $61.71 \%$ from cow dung and poultry droppings, respectively. Another study Li et al., (2013) considered that rabbit dung is a perfect substrate for biogas generation because applying rabbit dung as a substrate for biogas production generate high yield at a short fermentation period at the same time, both of quantity and variety of the inoculates have to take into consideration for the purpose of gain the superior parameter for fermentation.

This paper explores a simplistic study to predict the biogas production from animal waste slurries and compared it with its potential from local biomasses and its chemical composition under different mixture rates. Furthermore, the possibility of comparing the actual heat/electric energy of 
the wastes and with its potential values. In addition, measure the relationship between the biomass composition based on the chemical analysis under different waste ratio and the biogas production of the wastes, it would be possible to predict the heat/electric energy which can be utilized in the rural sector. And finally, evaluation the biogas production from home scale fermenter to cover livelihood requirements in for the rural community.

\section{MATERIAL AND METHOD}

In this part the experimental approach and the methods were used for the experiment estimation will be explained. The goal of the laboratory experiments in this research was to concise the use and estimation of the famous animal wastes as a substrate for biogas production.

The research was carried out on two trials, the first one done in a small-scale model, as shown in picuture (1) while the second one done in home scale digester $(68 l)$. The trials were carried out in a biogas laboratory at the Department of Agricultural Engineering, Faculty of Agriculture, Zagazig University.

\section{The animal wastes:}

Three different wastes were studied (cattle dung, poultry, and rabbit droppings) were collected from the experimental farm of the Faculty of Agriculture. The slurries were preparing by adding the water in the ratio of 1:1 $(w / w)$ to the different combination and manually homogenized before setting them into the digesters. Every slurry was replicated three times under similar condition from the beginning until the end in order to decrease the mistake risk. Starter from old digester has been adding to all digesters in order to increase the microbial activity. The fermentation process continues until the biogas production reached a minimum and neglected amount.

\section{Experimental setup to the first trial:}

The first anaerobic digest trial has done in laboratory single scale, batch reactors (Erlenmeyer flasks), which were locked with glass stoppers that have a hole linked to a collector gas holder via a PVC tube. The batch reactors put into a water bath and shaken up at constant temperature. The outcome biogas was collected in a gas holder unit and estimated by the water displacement; 
these units were previously calibrated by the scale in liters. A photo of this batch experiment setup is illustrated in Fig. (1).

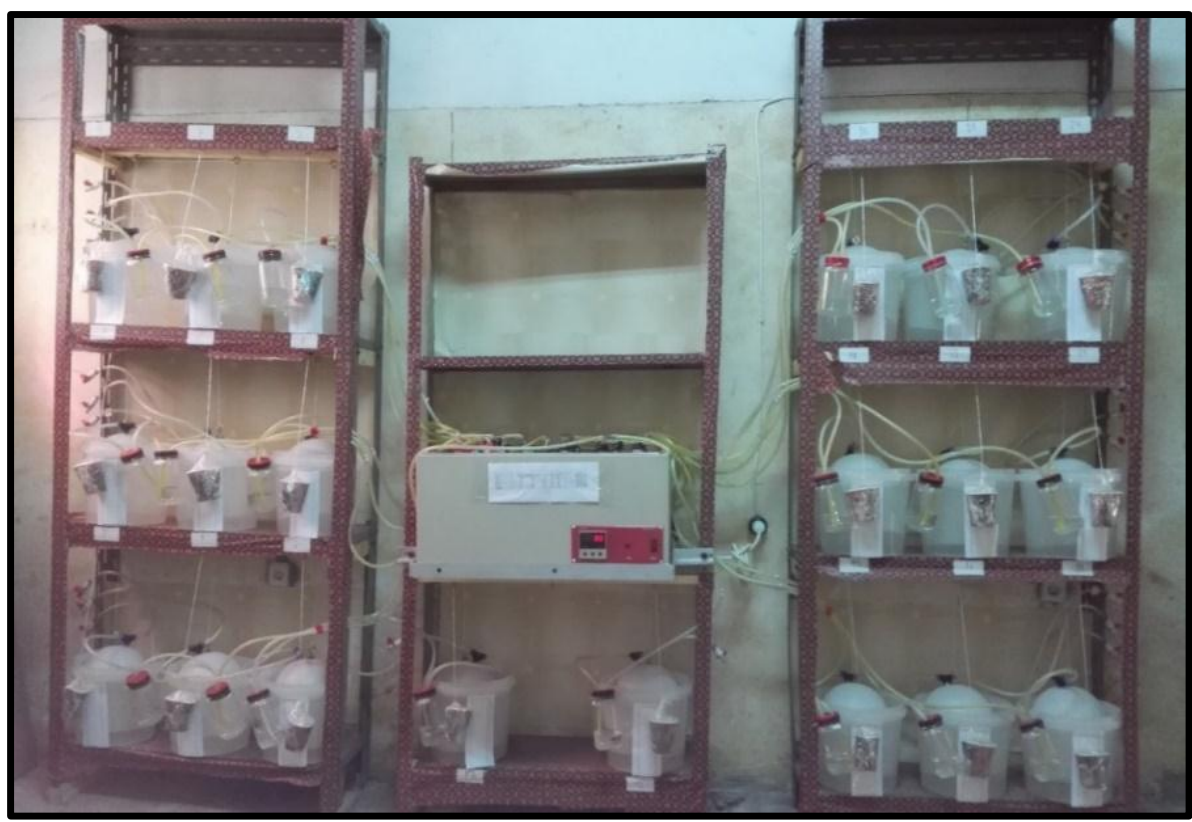

Fig. 1: Laboratory-Batch experiment setup

The different combinations were prepared with different percentage of wastes, are shown in Table 1.

Table 1: The different combinations from animals' wastes.

\begin{tabular}{|c|l|}
\hline No. Mixture & Mixing ratios \\
\hline R1 & $100 \%$ cattle dung \\
\hline R2 & $66 \%$ cattle dung $+34 \%$ rabbit droppings \\
\hline R3 & $50 \%$ cattle dung $+50 \%$ poultry droppings \\
\hline R4 & $66 \%$ cattle dung $+34 \%$ poultry droppings \\
\hline R5 & $60 \%$ cattle dung $+40 \%$ poultry droppings \\
\hline R6 & $25 \%$ cattle dung $+75 \%$ poultry droppings \\
\hline R7 & $50 \%$ cattle dung $+25 \%$ poultry $+25 \%$ rabbit droppings \\
\hline R8 & $50 \%$ cattle dung $+34 \%$ poultry $+16 \%$ rabbit droppings \\
\hline R9 & $34 \%$ cattle dung $+33 \%$ poultry $+33 \%$ rabbit droppings \\
\hline
\end{tabular}

The fermentation was done at constant mesophilic temperature $38^{\circ} \mathrm{C}$. Also, it is important during the course of the research, take care that the fermentation material is sufficiently mixed by manual shaking to the flasks each day at least two times. 


\section{Experimental setup to the second trial:}

The second experiment was done using the best mixture R6 (25\% cattle dung $+75 \%$ poultry droppings), which produced the highest methane production in the first trial. In this experiment, a constructed home-scale biogas plant was used, the biogas plant consists of the digester with a gas collector. The fermentation has done under mesophilic temperature $38^{\circ} \mathrm{C}$. The stirring process was conducted by a mechanical rotating paddle. In batch anaerobic co-digestion the total volume of the digester was a $68 l, 53$ $l$ of it digestion volume. The reactor has been charged by $5 \%$ starter (inoculum) in order to improve the microbial activity. The stirring system was turned on at three different periods of choppy agitation. The effect of intermittent agitation on the methane yield and retention time spent for complete fermentation were examined.

\section{Experimental analysis}

All raw materials were analyzed, the total solid percentage (TS\%) was measured after a 24 -hour drying period at $105^{\circ} \mathrm{C}$, the organic dry matter was evaluated based on ash percentage after incineration at $550^{\circ} \mathrm{C}$ for three hours. The $\mathrm{pH}$ values were measured before and after the fermentation, a Jenway3020 digital was utilized for this analysis, $\mathrm{pH}$ values for all slurry ranging between 7 and 8 were appropriate for anaerobic digestion.

Total lipid was determined according to Bligh and Dyer (1959), while total protein was measured based on the standard method AOAC (2000). The organic carbon was estimated before trial applying Walkley-Black method while nitrogen was measured according to Kjiedhal method, respectively and the $\mathrm{C} / \mathrm{N}$ ratios were ranging between $15-21 \%$ were suitable for anaerobic digestion. The Physicochemical properties of wastes show in Table 2.

Table 2 :The Physicochemical properties of the undigested wastes.

\begin{tabular}{|l|c|c|c|}
\hline Substance & Carbohydrate \% & Protein\% & Fat\% \\
\hline Cattle dung & 0.65 & 10.10 & 0.25 \\
\hline Poultry droppings & 1.70 & 14.50 & 0.30 \\
\hline Rabbit droppings & 1.76 & 12.68 & 0.15 \\
\hline
\end{tabular}

Both of the theoretical biogas and methane yield were stoichiometry evaluated, assuming that the fermentation is done completely to carbohydrate, fat, and protein under standard temperature and pressure; the 
evaluation is done according to Jorgensen (2009) This is illustrated in Table3.

Table 3: The Biogas and methane production at complete digestion.

\begin{tabular}{|l|c|c|c|}
\hline Substance & $\mathbf{m} \boldsymbol{l}$ biogas/g & $\mathbf{m} \boldsymbol{l} \mathbf{~ C H} / \mathbf{g}$ & $\mathbf{C H}_{\mathbf{4}} \%$ \\
\hline Carbohydrate & 830 & 415 & 50.0 \\
\hline Protein & 793 & 504 & 63.6 \\
\hline Fat & 1,444 & 1,014 & 70.2 \\
\hline
\end{tabular}

Another method used stoichiometrically, to estimate the theoretical biochemical methane potential (BMP) based on organic fraction composition, which estimated using the different organic compounds following Bushwell's formula according to Nielfa et al., (2015)

BMP $=415$ carbohydrates $\%+496$ proteins $\%+1014$ lipids \%

In contrast, the produced biogas was stored in a biogas holder and was measured by a calibrated water replacement method.The actual methane percentage was measured by injecting a biogas sample into a tube filled with $40 \%$ potassium hydroxide in order to $\mathrm{CO}_{2}$ take off so both of $\mathrm{CH}_{4}$ and $\mathrm{CO}_{2} \%$ were estimated by subtracting the inlet gas sample volume from outlet volume cited by Ezekoye and Okeke (2006).In the experiment beginning normally the reading be daily then the frequency of reading can be reduced to once every two or three days. There is also, a vital point to be considered that measure methane percentage be regularly because that's not sufficient to estimate the methane concentration just once during the test period.

\section{The calorific value}

The evaluation of the potential energy gives the opportunity to understand the losses of energy through the fermentation process. The comparison between the theoretical energy and the positive output energy (methane production) given the opportunity to estimate the energy lost and energy in fermented residues. The energy comparison can be done via physical aspects such as calorific value. The balance between the different waste's energy and methane production from them is one of the most important objectives in this research.

The energy in the gas phase estimated via measure the gas production and methane percentage in it. The actual and potential methane yield expressed per liter to fresh kilogram $(l / \mathrm{kg})$ or kilogram of volatile solid $\left(l / \mathrm{kg}_{\mathrm{vs}}\right)$. The 
calorific value (heat released during its combustion) from methane gas according to (OECD/IEA Electricity Information) is $50 \mathrm{MJ} / \mathrm{kg}$ ، the methane density $=0.72 \mathrm{~kg} \cdot \mathrm{m}^{-3}$ so the calorific value be 36 megajoules per cubic meter

$$
\mathbf{C} \cdot \mathbf{V}=\mathbf{M} \cdot \mathbf{P} \times \mathbf{F} \mathbf{c}
$$

Where: $\mathrm{C} . \mathrm{V}=$ Calorific value $(\mathrm{KJ} / \mathrm{kg}), \mathrm{M} . \mathrm{P}=$ total methane production $(l / \mathrm{kg})$, and $\mathrm{F}_{\mathrm{c}}=$ conversion factor $=36\left(\mathrm{MJ} \cdot \mathrm{m}^{-3}\right)$

\section{Energy generation}

Various kinds of wastes can be used as substrates for methane production; Accordingly, it was important compares the energy output from the different mixing of feedstocks and the energy potential from it that can be applied for energy production. According to Stucki et al., (2011) and Achinas et al., (2017) the energy produced from different feedstocks can be assessment as $35 \%$ of energy efficiency combined heat power with heating value $21 \mathrm{MJ} \cdot \mathrm{m}^{-3}$ is $1 \mathrm{~kW} . \mathrm{h}=3.6 \mathrm{MJ}$.

$$
\mathbf{E} . \mathbf{G}=\frac{\mathbf{B} . \mathbf{Y} \times \mathbf{H} . \mathbf{V} \times \boldsymbol{\eta}_{\boldsymbol{e}}}{\boldsymbol{F}}
$$

Where: E.G = The Energy generation $(\mathrm{kW} \cdot \mathrm{h}), \mathrm{B} . \mathrm{Y}=$ Biogas yield $\left(\mathrm{m}^{3}\right)$, $\mathrm{H} . \mathrm{V}=$ Heating value $\left(\mathrm{MJ} \cdot \mathrm{m}^{-3}\right), \eta_{\mathrm{e}}=$ electrical efficiency, and $\mathrm{F}=$ conversion factor $=3.6\left(\mathrm{MJ} .(\mathrm{kW} \cdot \mathrm{h})^{-1}\right)$

\section{RESULTS AND DISCUSSION}

\section{The expected and actual of biogas and methane production}

The biogas and methane production from different substrates were measured and the values were compared with the theoretical biochemical potential which evaluated by the stoichiometric method depends on carbohydrate, protein, and fat percentage based on (Bushwell's and jorgensen formula).

Undoubtedly, the potential yields are the primary indicator of the production of methane as well give an idea of how successful this combination to gain significant yield. The measurements and calculated values are summarized in Table 4 and Fig. 2.

The results show that the biogas yield was between 80.86 and $48.23 / / \mathrm{kg}$ fresh, while methane yield ranged between, 270.81 and $153.47 / / \mathrm{kg}_{\mathrm{vs}}$. 
Table 4: The variation between the expected and actual yields.

\begin{tabular}{|c|c|c|c|c|}
\hline $\begin{array}{c}\text { Wastes } \\
\text { combination }\end{array}$ & $\begin{array}{c}\text { Theoretical } \\
\text { Biogas yield } \\
{\left[l / \mathrm{kg}_{\text {fresh }}\right]}\end{array}$ & $\begin{array}{c}\text { Actual } \\
\text { biogas yield } \\
{[l / \mathrm{kg} \text { fresh }]}\end{array}$ & $\begin{array}{c}\text { Theoretical } \\
\text { Methane yield } \\
{[l / \mathrm{kg} \text { fresh }]}\end{array}$ & $\begin{array}{c}\text { Actual } \\
\text { methane yield } \\
{\left[l / \mathrm{kg}_{\text {fresh }}\right]}\end{array}$ \\
\hline R1 & 89.10 & 48.23 & 56.14 & 30.16 \\
\hline R2 & 98.51 & 51.65 & 61.67 & 36.59 \\
\hline R3 & 111.26 & 69.63 & 69.66 & 51.09 \\
\hline R4 & 103.87 & 57.36 & 65.15 & 36.75 \\
\hline R5 & 106.83 & 57.65 & 66.95 & 37.68 \\
\hline R6 & 122.34 & 80.86 & 76.42 & 57.84 \\
\hline R7 & 107.24 & 66.59 & 67.05 & 47.62 \\
\hline R8 & 108.59 & 73.42 & 67.92 & 51.82 \\
\hline R9 & 113.28 & 77.14 & 70.68 & 54.83 \\
\hline
\end{tabular}

The results also show that the yield can be optimized by increasing the organic content via using co-substrates. It can be seen from the above data that, the methane production increase by $76.46 \%-11.02 \%$ when the cattle dung codigested with another animal wastes. At the same time, using some feedstock as poultry droppings alone in anaerobic digestion face a different challenge as reviewed by Triolo et al., (2011) and Wang et al., (2013).

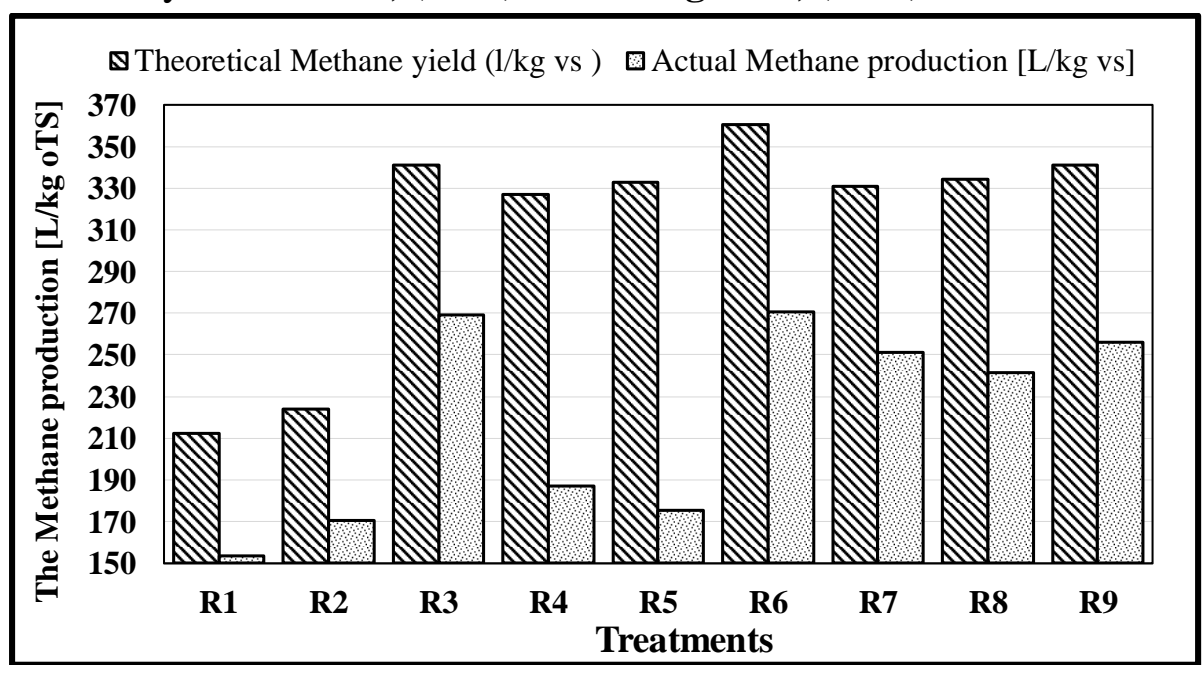

Fig. 2: The theoretical and actual methane production $[l / \mathrm{kg} \mathrm{vs}]$

Also, one of the major findings of this study was the importance of the percentage of raw material in the mixture. For example, the biogas production 
increase by $67.68 \%$ with combination R6 but it be $18.93 \%$ only with combination R4 compared with $100 \%$ cattle dung in spite of both consists of the same raw materials but the ratios were different. For this reason, not only the feedstocks synthesis important but row feedstocks percentages have to put into consideration.

Certainly, the actual yield of methane depended initially on by the substrate chemical composition which feeds to the fermenter. As a consequence, it is substantial to analyze the feedstock components to decide it's appropriate to anaerobic digestion.

From the data outlined in the previous table, the levels of the digestion (the decomposable part of organic matter) for different mixtures ranged between 52.73-78.94\%. Furthermore, it is quite predictable that some mixtures need to pretreatment, whereas the gap between its potential and actual production was big. The pretreatment can be done by increasing the connection between the particle organic of the different substrates by raising the agitation rate for example.

\section{The calorific value from a different combination of animal wastes.}

Nobody denies that methane is the worthiest component when biogas used as fuel, whereas other components haven't participated in a combustion process and ordinarily the other components washed out in order to purify biogas in order to obtain biogas with almost $100 \%$ methane. In agriculture scale, the organic wastes as animal dung are the main resources for biogas production. Until now it is no strict method to calculate the energy potential of biogas, but all previous literature states the considerable potential of the biogas sector. Both of the technical potential calorific value calculated from theoretical methane yield and the actual one which evaluated from actual methane production are shown in Fig.3.

The results show that the calorific efficiency average $53.72-77.57 \%$. Accordingly, Thus, the selection for the best combination depending on the requirements from the biogas plant can be done besides selection the combinations need to pretreatment. Pretreatment can be applied for improving methane yield, for instance, increase the quality of feed substrate and the conditions of the fermentation, will provide a higher calorific value be enough to apply in many energy applications special in the rural energy sector. 


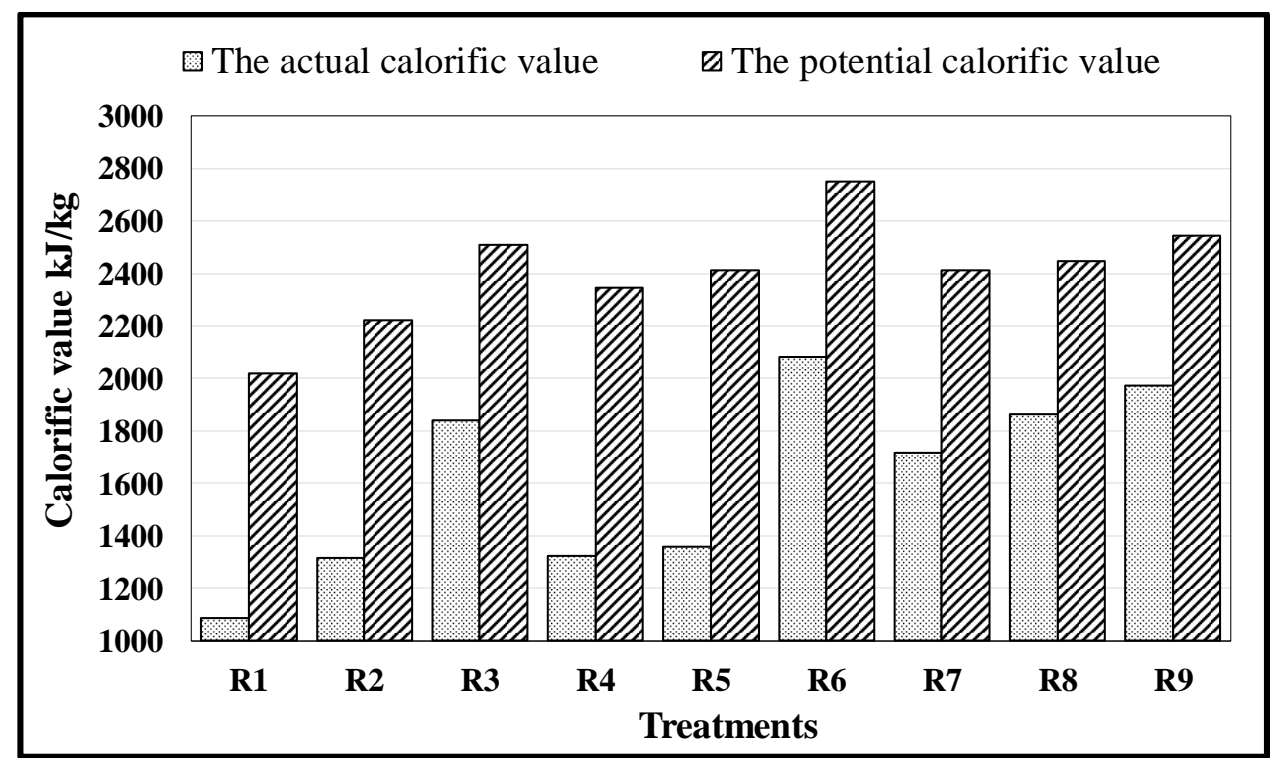

Fig. 3:The actual and potential calorific values.

\section{The Energy generation from a different combination of wastes}

Certainly, the accumulated energy can be estimated when the methane production were collected, whereas the experiment continues until the production became neglected. Thus, it can be expected that you will end up with a value that is close to the potential output of the biomass. The potential energy can be evaluated by analysis biomass components, whereas the composition has a direct effect on methane contains, therefore on its electricity production.

As can be seen from Fig. 4 shows the comparison between the energy which can be generated from the actual biogas production and the theoretical one which accounted depend on the Physicochemical properties of the undigested wastes.

The energy generation ranged between 98.46 and $165.10 \mathrm{~kW} \cdot \mathrm{h}$ was calculated based on the actual biogas production while was181.91-249.79 $\mathrm{kW} \cdot \mathrm{h}$ when estimate based on theoretical biochemical potential.

From the outcome of this investigation, it is possible to conclude that the electricity produced efficiency ranged between $52.43-68.09 \%$, so It can be inferred that some mixture of feedstocks needs pretreatment to increase the efficiency and make it more economical. 


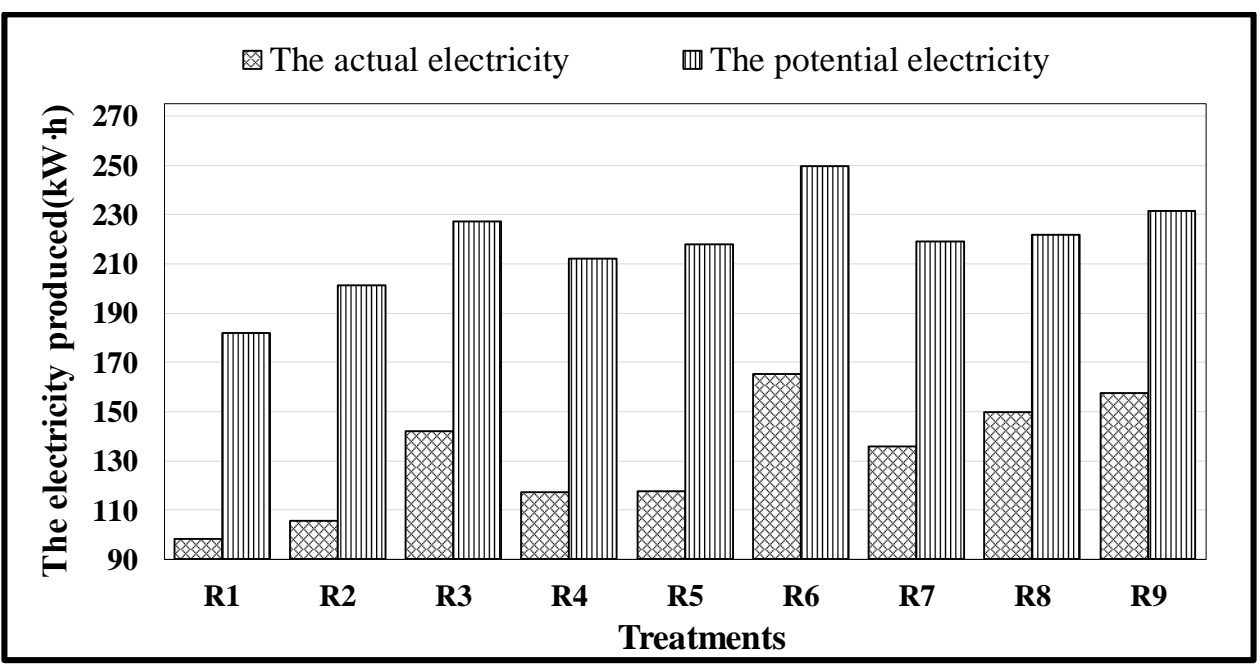

Fig. 4:The actual and potential electricity generation.

The production from the home-scale digester and its applications

In general, the stirring process during digestion is a very significant step because its effect on increasing the connection between microorganisms and particle organic substrate, improve the biodegradability rate, temperature distribution, make a homogenous mixture and support biogas movement to the storage unit cited by Lemmer et al. (2013). Both of biogas and methane yield was recorded daily under different stirring rates. Fig.(5) shows the effect of different agitation rates on methane production and the retention time.

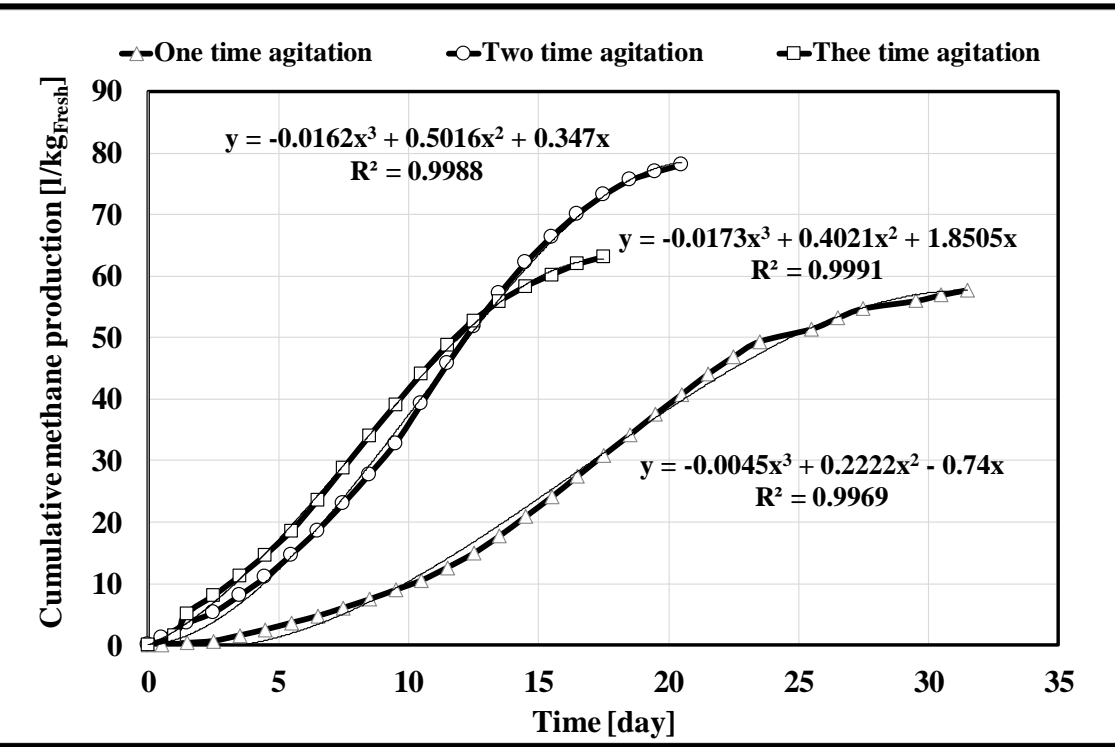

Figure 5:The daily methane yield under different agitation rates. 
The results show that the cumulative methane yield ranged between 78.1 and $57.74 l / \mathrm{kg}$. Furthermore, the methane yields increased with increasing the stirring rate to two times per day.

Conversely, increase the agitation rate to three times per day decrease the methane production by $14.73 \%$; It is quite predictable that the stirring more than needed lead to limit the performance of the fermentation and uses more energy in mixing. This is in agreement with Karim et al., (2005) opinions, who informed that the increase in the stirring process doesn't improve the fermentation if the solid concentration in the fed slurry not high.

By the same token, the change in agitation strategies effect on the time period required to needed for complete fermentation in a positive way. There is also, however, a further point to be considered, increase in the agitation rate more than required lead to disturbance the microorganism activity and it is granted that the activity of the bacteria is the condition for anaerobic digestion successful.

The relationship between the number of stirring and the retention time is inverse relation. the retention time was 31,20, and 17 days for one, two, and three stirring times per day, respectively.

The data were analyzed by adopting regression models using Polynomial type. The Regression Equation is $\mathrm{y}=\mathrm{a}+\mathrm{bx}_{\mathrm{s}}+\mathrm{cx}_{\mathrm{s}}{ }^{2}+\mathrm{dx}_{\mathrm{s}}{ }^{3}$, Where y can be represented as the cumulative methane yield ( $y$ value in the curve), $x$ is the retention time ( $x$ value in the curve), while $a, b, c$ are regression constants. The regression equation can be used to developing predictive models for the generation of methane under different agitation rate for various retention time. From the curve the regression equation for best methane production was $\mathrm{y}=0.347 \mathrm{x}+0.5016 \mathrm{x}^{2}-0.0162 \mathrm{x}^{3}$.

Based on the actual biogas and methane production from the experiment both of heat values and electricity generation have been counted, so the suitable application of biogas can be selected based on these values. Table 5 summarizes the estimated electricity generation $(\mathrm{kW} \cdot \mathrm{h})$ and calorific values $(\mathrm{kJ} / \mathrm{kg})$.

The data explained the importance of good agitation where the calorific values increase by $35 \%$ while the electricity can be more generation by $32 \%$ with two times agitation. 
Table (5): The estimated values of heat energy and electricity generation under different agitation rate.

\begin{tabular}{|l|c|c|}
\hline Number of agitation & $\begin{array}{c}\text { calorific values } \\
\mathbf{~} \mathbf{J} / \mathbf{k g}\end{array}$ & $\begin{array}{c}\text { Electricity generation } \\
\mathbf{~} \mathbf{W} \cdot \mathbf{h}\end{array}$ \\
\hline One time per day & 2078.96 & 169.20 \\
\hline Two times per day & 2810.83 & 222.88 \\
\hline Three times per day & 2272.23 & 190.05 \\
\hline
\end{tabular}

A preliminary study has been carried out to meet the energy demands of the livelihood of rural villagers to the biogas produced from small house digester (68 $l$ ). The study has been done basis per household according to Vögeli (2014), and the data are summarized in Table 6. From the experiment result of the home-scale biogas digester, the average biogas production was 3993.87 $l /$ month from $25 \mathrm{~kg}$ only from animal wastes.

Table (6): The consumption rates of biogas for different applications.

\begin{tabular}{|l|c|l|c|}
\hline \multicolumn{1}{|c|}{ Biogas application } & $\begin{array}{c}\text { Consumption } \\
\text { Rate } l / \mathrm{h}\end{array}$ & \multicolumn{1}{|c|}{$\begin{array}{c}\text { Average of biogas } \\
\text { requirement }\end{array}$} & $\begin{array}{c}\text { Cover livelihood } \\
\text { requirements by } \\
\text { biogas }\end{array}$ \\
\hline $\begin{array}{l}\text { Household cooking } \\
\text { stove }\end{array}$ & $200-450$ & $\begin{array}{l}\text { Cooking }(325 l / \mathrm{h} * 3)= \\
975 l / \text { day }\end{array}$ & 4 -day work \\
\hline $\begin{array}{l}\text { Refrigerator }(100 l) \\
\text { depending on outside } \\
\text { temperature }\end{array}$ & $30-75$ & $\begin{array}{l}\text { Refrigerator }(52.5 l / \mathrm{h} * 6) \\
=315 l / \text { day }\end{array}$ & 12 -day work \\
\hline $\begin{array}{l}\text { Gas lamp, equivalent to } \\
60 \text { W bulb }\end{array}$ & $120-150$ & $\begin{array}{l}\text { Lighting }(140 l * 3.5 \mathrm{~h} * \\
2 \text { lamps })=980 l / \mathrm{day}\end{array}$ & 4 -day work \\
\hline $\begin{array}{l}\text { Biogas engine per } \\
\text { brake horsepower }(746)\end{array}$ & 420 & $\begin{array}{l}\text { Biogas engine need } 420 \\
l / \mathrm{h}\end{array}$ & 9 hours \\
\hline $\begin{array}{l}\text { Generation of } 1 \mathrm{kWh} \text { of } \\
\text { electricity with biogas } \\
\text { per diesel mixture }\end{array}$ & 700 & $\begin{array}{l}\text { Generation of } 1 \mathrm{kWh} \text { of } \\
\text { electricity need } 700 l / \mathrm{h}\end{array}$ & 5 hours \\
\hline
\end{tabular}

Regarding the biogas applications and the requirements are presented in Table 6 , it is clear that on an average, the biogas requirement per household is estimated to be $975,315,980 l$ per day for cooking, refrigerator and gaslamp,respectively. In this way, the biogas production from the small home unit can cover these livelihoods for 4,12 and 4 days, respectively thus biogas might be able to take the place of the conventional sources such as kerosene, dung cake, and firewood. 
Hence, the biogas production from animal wastes can not only support the living environment of rural people but also supply communities with clean energy.

Given the advantages of outlined in the previous paragraph, it is quite predictable that apply biogas in rural communities lead to a significant decrease in air pollution and a reduction in $\mathrm{CO}_{2}$ emissions Furthermore, improve conventional fuel savings as suggested by Liu et al., (2014).

\section{CONCLUSION}

This paper is a modest contribution to the ongoing discussions on the study the extent of possibility the Biomethanization process successful with the lowcost available feedstocks and its benefits for heating and electricity in the rural community. Furthermore, the comparison between both of the actual and potential heat/electricity produced in order to further investigation to increase the output energy and gross profit margin off bioenergy alternative.

The research was done on two experiments, the first one done using a different combination of animal wastes in a small-scale model while the second fermentation achieved in home scale digester to the best combination of waste in methane production from the first trial, under different agitation rates.

The first experiment shows that the co-digestion of cattle dug with another substrate especially poultry waste, which faces challenges if digested alone led to increasing the biogas yield by $67.68 \%-7.10 \%$. As a result of increasing the organic content and optimize the conditions of anaerobic digestion.

Another significant factor is the percentage for every row feedstock in the mixture, whereas in some synthesis the production increase by $67.68 \%$ (25\% cattle dung $+75 \%$ poultry dropping) compared to using cattle dung only while the increasing be only $18.93 \%$ with $(66 \%$ cattle dung $+34 \%$ poultry droppings), although both are composed of the same types of animal residues but in different proportions.

The actual calorific values ranged between 1085.72- $2082.10 \mathrm{~kJ} / \mathrm{kg}$. Correspondingly, The potential calorific value which calculated from theoretical methane production was 2020.91- $2751.01 \mathrm{~kJ} / \mathrm{kg}$. Hence, the combinations can be selected to be high enough for applying in energy applications.

In the second experiment, The best feedstocks synthesis (25\% cattle dung + $75 \%$ poultry droppings) from the first trial was select to digest.The biogas 
yield from home digester was $3993.87 \mathrm{l} / \mathrm{month}$ from $25 \mathrm{~kg}$ only of fresh animal wastes, this amount was enough to use 4,12 and 4 days to cooking, Refrigerator, and Gaslamp, respectively,which led to decrease the using of conventional sources and improve the healthy living in rural communities.

Summing up the results, it can be recommended that, analysis of the raw substrate it is an essential measure in order to good digestion. By analysis, the expected yield can be estimated and Identification the best synthesis of wastes which produces the yield needed to cover the requirements in the rural communities. The biogas technology in the rural sector should be encouraged to cover the daily needs of the community at the same time the agricultural and animal wastes management to reduce its energy losses.

\section{REFERENCES}

Achinas, S., Achinas, V. and Euverink, G.J.W., 2017. A technological overview of biogas production from biowaste. Engineering, 3(3), 299-307.

Alfa, I.M., Dahunsi, S.O., Iorhemen, O.T., Okafor, C.C. and Ajayi, S.A., 2014. Comparative evaluation of biogas production from Poultry droppings, Cow dung and Lemon grass. Bioresource technology, 157, 270-277.

AOAC Official Methods, 2000. Official methods of analysis of AOAC international

Bligh, E.G. and Dyer, W.J., 1959. A rapid method of total lipid extraction and purification. Canadian journal of biochemistry and physiology, 37(8), 911-917.

Cu, T. T. T., H. C. Pham, T. H. Le, V. C. Nguyen, X. A. Le, X. T. Nguyen, and S. G. Sommer. 2012. Manure management practices on biogas and non-biogas pig farms in developing countries - using livestock farms in Vietnam as an example. Journal of Cleaner Production, 27, 64-71.

Deublein, D. and Steinhauser, A., 2008. History and status to date in other countries. Biogas from waste and renewable resources: An introduction. Weinheim: Wiley-VCH Verlag GmbH \& Co. KGaA.

Elfeki, M. and Tkadlec, E., 2015. Treatment of municipal organic solid waste in Egypt. Red, 45، 0-16.

Ezekoye, V.A. and Okeke, C.E., 2006. Design, construction, and performance evaluation of plastic biodigester and the storage of 
biogas. The Pacific Journal of Science and Technology, 7(2), 176184.

Hassan, E.A., 2003. Biogas Production from Forage and Sugar Beets: Process Control and Optimization-Ecology and Economy (Doctoral dissertation, Univ. Kassel,Germany, Fachgebiet Agrartechnik).

Jorgensen, P.J., 2009. Biogas-green energy.2nd ed .Digisource Denmark: Faculty of Agricultural Sciences, Aarhus University.

Karim, K., Hoffmann, R., Klasson, K.T. and Al-Dahhan, M.H., 2005. Anaerobic digestion of animal waste: Effect of mode of mixing. Water research, 39(15), 3597-3606.

Lemmer, A., N., Hans-Joachim, J., Sondermann, 2013. How Efficient are Agitators in Biogas Digesters? Determination of the Efficiency of Submersible Motor Mixers and Incline Agitators by Measuring Nutrient Distribution in Full-Scale Agricultural Biogas Digesters Energies, 6(12), 6255-6273.

Li, Y.J., Liu, L.C., Yang, B., Zhang, W.D., Yin, F., Xu, L., Zhao, X.L., Liu, J., Chen, Y.B. and Liu, S.Q., 2013. Experimental study on biogas production by mesophilic fermentation for rabbit dung. In Advanced Materials Research (Vol. 763, 160-164). Trans Tech Publications.

Liu, A., Xu, S., Lu, C., Peng, P., Zhang, Y., Feng, D. and Liu, Y., 2014. Anaerobic fermentation by aquatic product wastes and other auxiliary materials. Clean Technologies and Environmental Policy, 16(2), 415-421.

Machunga-Disu, L. L. and Machunga-Disu, Z., 2012. Sustainable management of natural resources and the need for revenue transparency, subsidy reform and full deregulation: The Transformation from Fossil Fuel to Green Energy, Green Deal Nigeria. A publication of Heinrich Boll Stiftung, Nigeria.

Miah, M.R., Rahman, A.K.M.L., Akanda, M.R., Pulak, A. and Rouf, M.A., 2016. Production of biogas from poultry litter mixed with the co-substrate cow dung. Journal of Taibah University for Science, 10(4), 497-504.

NIST Chemistry WebBook .OECD/IEA Electricity Information (various editions) International Gas Union, Natural Gas Conversion Guide. 
Nielfa, A., Cano, R. and Fdz-Polanco, M., 2015. Theoretical methane production generated by the co-digestion of organic fraction municipal solid waste and biological sludge. Biotechnology Reports, 5,14-21.

Stucki, M., Jungbluth, N. and Leuenberger, M., 2011. Life cycle assessment of biogas production from different substrates. Final report. Bern: Federal Department of Environment, Transport, Energy and Communications, Federal Office of Energy.

Triolo, M.J., Sommer, G.S., Moller, B.H., Weisbjerg, R.M., Jiang Y.X., 2011. "A new algorithm to characterize biodegradability of biomass during anaerobic reaction: Influence of lignin concentration on methane production potential. Bioresource technology, 102(20), 9395-9402.

Vögeli, Y., 2014. Anaerobic digestion of biowaste in developing countries: Practical information and case studies. Eawag-Sandec.

Wang, X., Yang, G., Li, F., Feng, Y., Ren, G., Han, X., 2013. Evaluation of two statistical methods for optimizing the feeding composition in anaerobic co digestion: mixture design and central composite design. Bioresource technology, 131, 172-178.

Weiland, P., Verstraete, W. and Van Haandel, A., 2009. Biomass digestion to methane in agriculture: A successful pathway for the energy production and waste treatment worldwide. Biofuels.

$$
\text { الملخص العربـى }
$$

\section{مقدرة الغاز الحيوي كطاقة مستدامة لتلبية سبل المعيشة الريفية

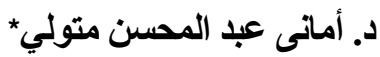

إن زيادة الطلب العالمي على الطاقة النظيفة أدى الى الاتجاه الى استغلال مصادر المخلفات الحيو انية

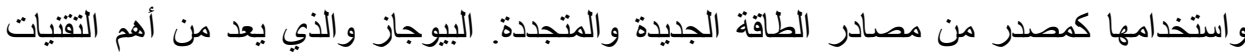

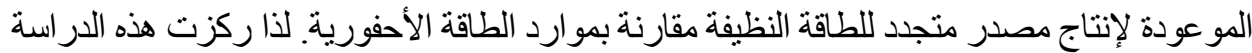

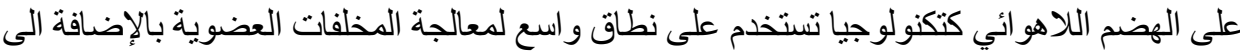

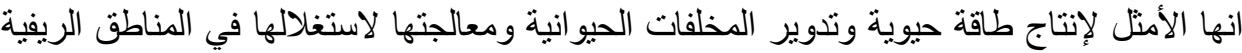

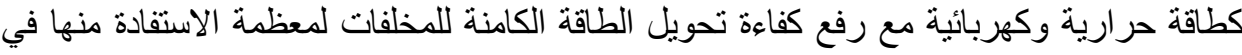

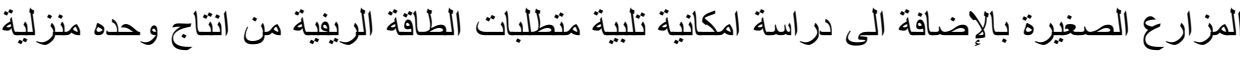


وتهدف الدراسة الى: (1) اختيار التركيبة الأمتل من المخلفات الأكثر انتشار ا في المزارع الصغيرة

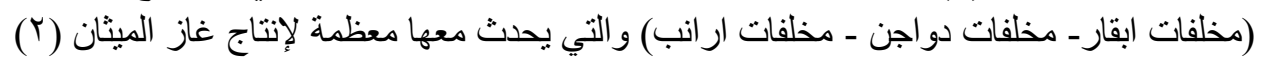

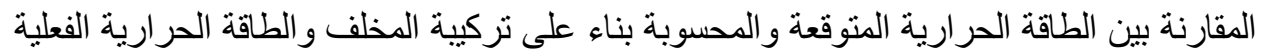

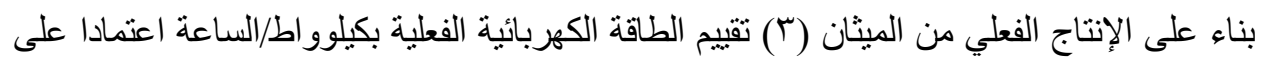

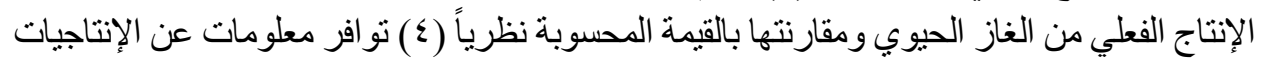

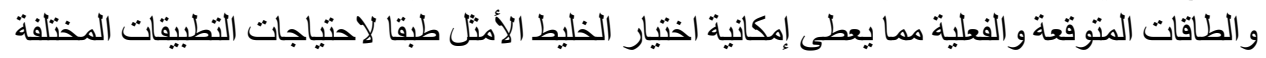

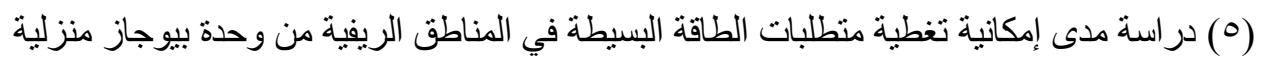

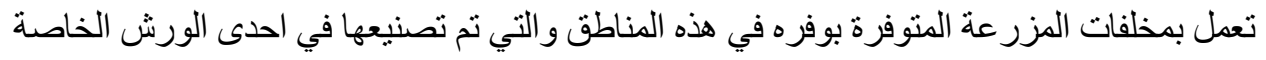

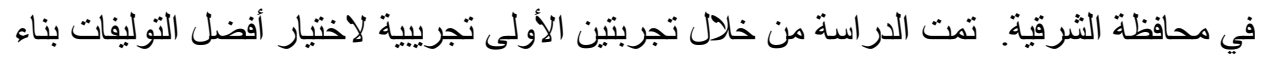

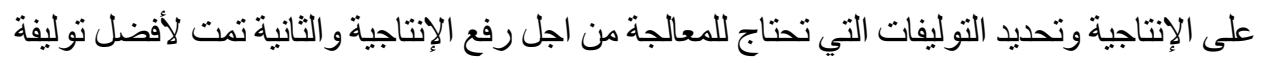
من التجربة الأولى على هضام منزلي لدر اسة مدى تغطية الاحتياجات الريفية البسيطة.

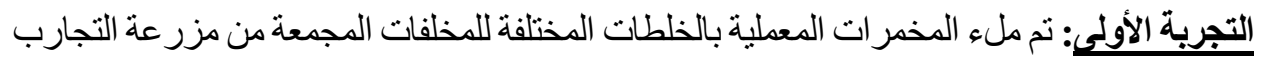

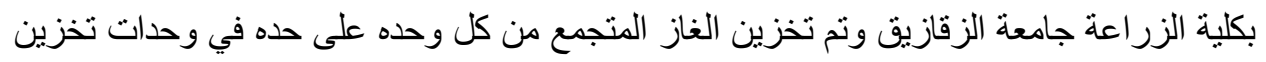

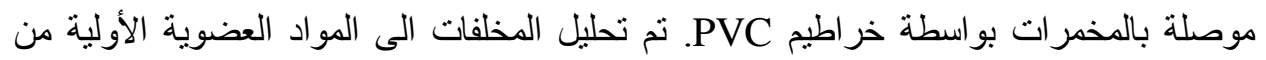

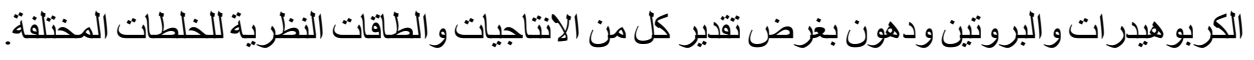

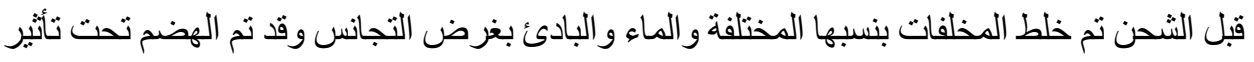

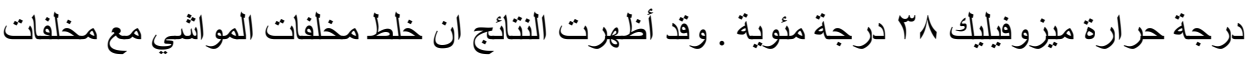

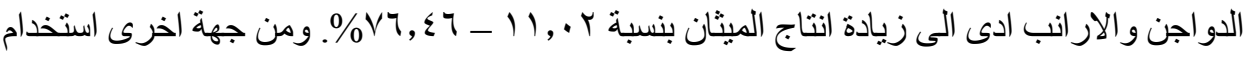

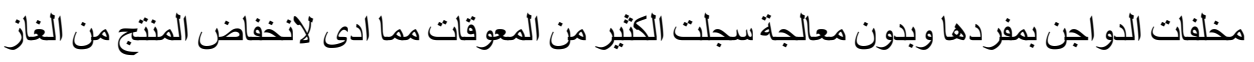
الحيوي او فنثل عملية التخمر.

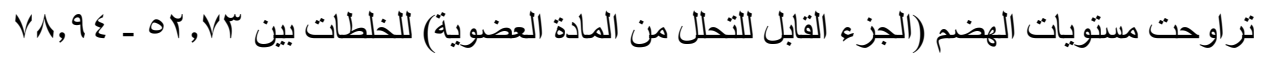

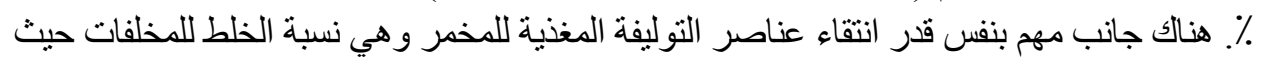

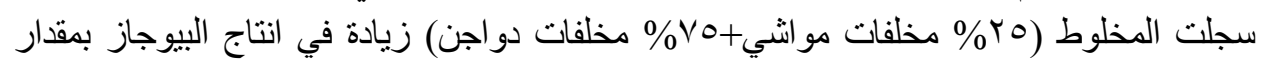

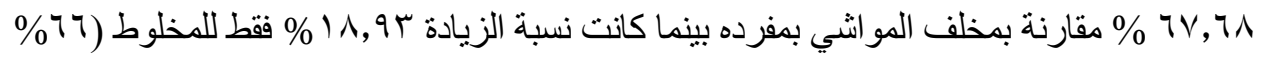

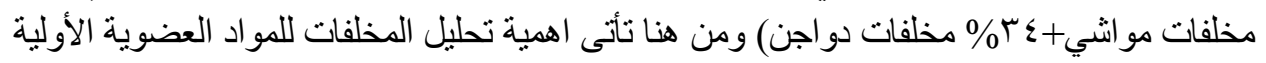

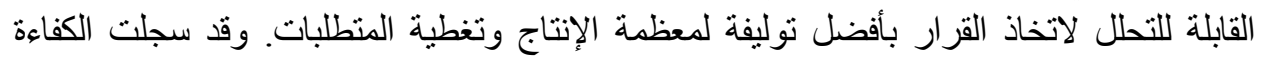

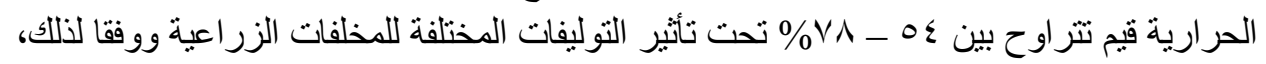

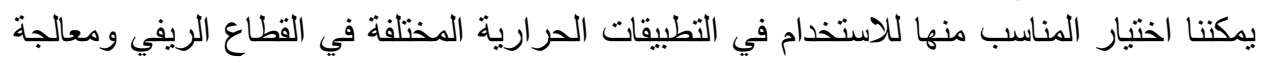

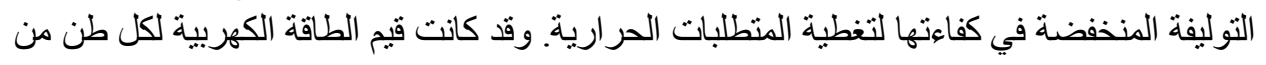

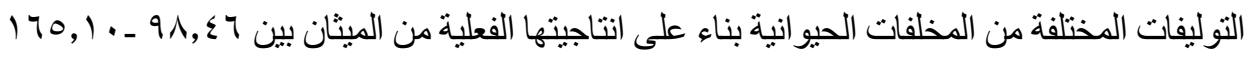

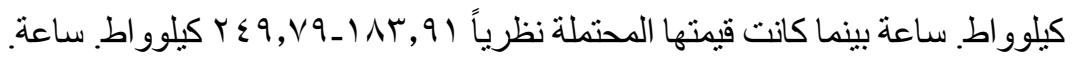

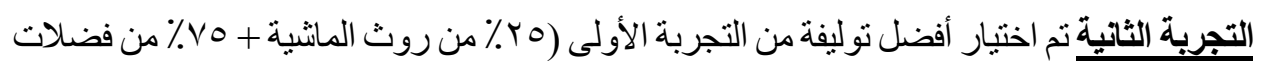

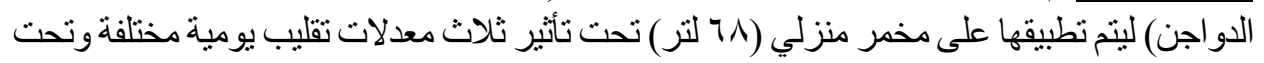
تأثير درجة حر ارة ميزوفيليك بغرض معظمة الإنتاج ودر اسة مدى تغطية الاحتياجات اليونية مئية الاساسية 


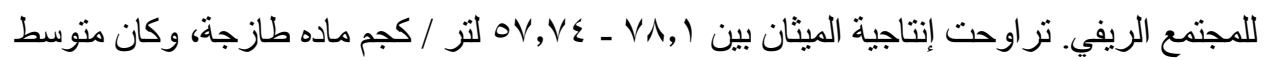

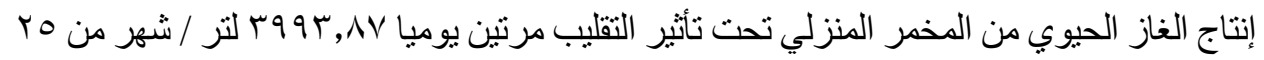
كجم فقط من المخلفات الحيو انية ومعادلة الانحدار كانت

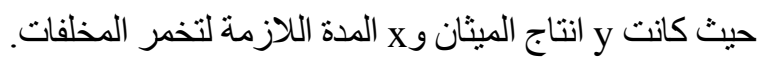

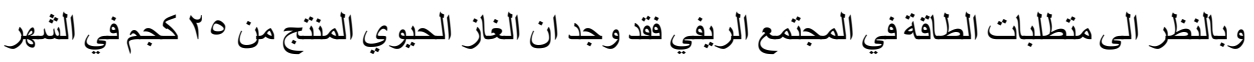

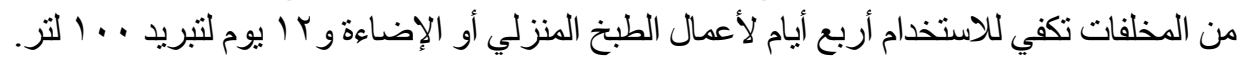

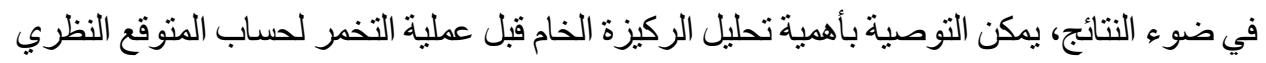

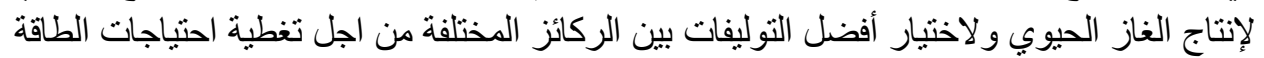

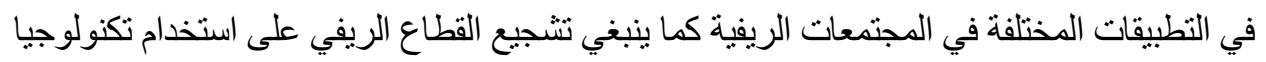

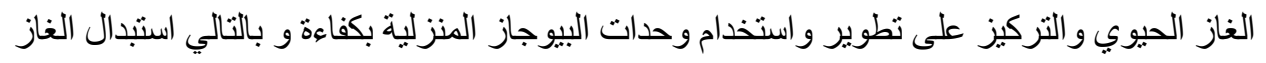

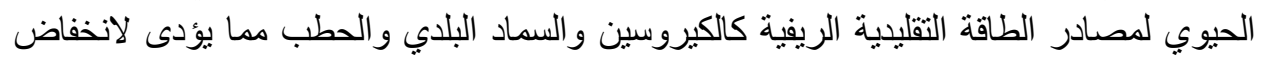

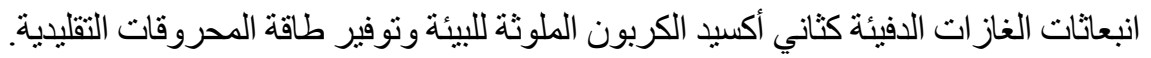

